\title{
SURVEY AND POPULATION DYNAMICS OF SOME LAND SNAILS INFESTING DIFFERENT PLANT HOSTS AT SHARKIA GOVERNORATE.
}

\author{
Kadry, W. M. ${ }^{(1)}$; Abd-Elmageed, A. E. ${ }^{(1)}$; Boules, M. W. ${ }^{(2)}$ \\ and Bayoumi, Shimaa, M. ${ }^{(2)}$ \\ 1) Plant Protection Department, Fac. of Agric., Ain Shams Univ 2).Plant \\ Protection Research Institute, A.R.C., Dokki, Giza, Egypt.
}

\begin{abstract}
The present investigation concerned to study some ecological, aspects of terrestrial snails infesting different plant hosts viz, some field, vegetable, horticultural, ornamental and aromatic plant crops at Sharkia Governorate. A randomly survey carried out to detriment the incidence of land snail species at different area i.e., Hehia, Belbies, Meniat Elkamh, Abou Hammad and Zagazig districts at . Results revealed that three species of land snails belonging to three families of order: Stylommatophora were found. The snails and their families were Family: Hygromiidae (Monach cartusiana), Succineidae (Succinea putris) and Helicidae (Eobania vermiculate). The recorded snails' species were varied in their incidence and it's level of infestation according to the location and host plants. M. cartusiana was dominant comparing with the other species; it was recorded in all surveyed area. M. cartusiana recorded the highest level and infestation on Egyptian clover (+++), Brood peen $(+++)$ and cabbage $(+++)$, especially at Hehia districts. The recorded land snail's species could be ranked according to their incidence in studied areas as following: M. cartusiana $>$ S. putris $>$ E. Vermiculate. However there were many studies conducted on the Population dynamic of snails M. cartusiana and E. Vermiculate at Sharkia Governorate, so snail of S. putris was subjected to study this fenomena in this investigation Results indicated that, S. putris was recorded on Egyptian clover with high density during spring months (March, April and May) throughout two successive seasons 2015/2016 and 2016/2017 at Hehia and Belbies distracts. Population density of S. putris slightly increased to reach its peck (27.8 and
\end{abstract}


35 individual) \& (37.4 and 42.4 individual) during April of growing season 2015/2016 and 2016/2017 at Hehia and Belbies districts respectively.

Keywords: Survey, Population dynamic, Succinea putris, Monach cartusiana, Eobania vermiculate land snail, Sharkia.

\section{INTRODUCATION}

Earlier, land snails in Egypt were not have a significant importance in agriculture environment. However in the last decats, importance of land snails as agriculture pests increased gradually till becomes one of major pests in some cases, land snails concerned a serious pests cause damage to wide variety of field crops, vegetables and fruit trees in many countries all over the world Godan(1983). In Egypt, Arafa (1997) found that, Monach cartusiana and Cochlicella acuta, infested caesarians and mandarin trees in AbouHammad district while Eobania verimculata was recorded on ornamental plants in Zagazig district. Ismail, (1997) mentioned that four species of land snails, i.e M. cartusiana, Helicella vestalis, E. vermiculata, and C. acuta were recorded on different crops at 17 localities representing 7 counties of Sharkia Governorate. Lokma, (2007) surveyed five districts of Sharkia Governorate such as Belbies, Fakous, Kafr-Saker, Meniet El-Kamh and Zagazig during the period from February to May in 2003 and 2004, He found that the glassy clover snail, M. cartusiana infested all crops in all localities of Sharquia Governorate, while the conical snail C. acuta was found in El-Katiba village (Belbies district). Abed (2017) land snails were recorded on several field crops i.e. Wheat, Egyptian clover, Broad bean, Barley, Maize and Sugar beet while vegetable crops i.e. Lettuce, Cabbage, Cucumber, Kidney bean, Eggplant, Onion, Okra, Tomato, Garlic, Dill and Parsley in 12 villages follow 
three districts in Sharkia Governorate.

The aim of this study was to through the light on the occurrence and seasonal population dynamics of some land snails on some associated with field crops at Sharkia Governorate.

\section{MATERIALS AND METHODS}

A: study area: Five main districts at Sharkia Governorate were chosen, some of these districts included more than one site (village). The study areas and their site were: Hahira district: (Al-Awasga - Hussien Timour and Kafr Abou Hatab), Belbies district: (Kafr Aioub), Meniat Elkamh district :( Elkarakra and Banadf), Abou Hammad district (El-Sheikh Gebil), Zagazig district :( El-Nakkaria, Bani Shebl, and Manshiet Abou Al-Akhdar).

B. host plants: The host plant species in this study were: field crops as Egyptian clover, (Trifolium alexandrinum); wheat (Triticum aestivum); broad bean (Vicia faba) and onion (Allium cepa); vegetable crops i.e. cabbage, (Brassica oleracea); lettuce (Lactuca sativa), horticultural crops such as navel orange (Citrus sinensis) and ornimental plants i.e. Palm trees (Cycas revoluta) and aromatic plants Mint (Mentha spicata) and Basil (Ocimum basilicum)

\section{c- Survey and population dynamic.}

C.1: Randomly survey of land snails infesting different host plants.: In all districts land snails species were counted early morning in each host plant area in addition to the snails on the host plant of each field crops using the quadrate sample size 50x50cm (Staikou et al., 1990). Samples of the land snails were collected in plastic box then transferred to the laboratory of 
plant protection instate identification of land snails done according to Godan (1983).

\section{C.2. Population dynamics of Succinea putris on the Egypt clover: This} study was conducted in two districts i.e. Hehia district (HussienTimour) village and Belbies district (Kafr Aioub) village during two growing seasonal 2015/2016 and 2016/2017, About one fadden cultivated with Egyptian clover in each village was selected Five replicates of quadrate sample size $(50 \times 50 \mathrm{~cm})$ per each Fadden were examined monthly intervals using the methods as mentioned previously.

\section{RESULTS AND DISCUSSION}

Several ecological studies studied comprise the identity of the land snails infesting different crops at Sharkia Governorate and population dynamics on several crops. Therefore, survey and population dynamics of some land snail's species were especially on major crops at Sharkia Governorate.

Survey studies of some land snails during 2015/2016 and 2016/2017 in five districts at Sharkia Governorate: Widely survey was carried out on some land snails infesting different crops at ten villages representing five districts at Sharkia Governorate. The results present in Table (1) revealed that three species of land snails were found on different crops, belonging to different families of order: Stylommatophore the families were: Hygromiidae (M. cartusiana), Succineidae (S. putris) and Family: Helicidae (E. vermiculata). The identified species varied in their incidence and level of infestation according to locality and host type. It was observed that $\mathrm{M}$. cartusiana was dominant compared with the other species since it was 110 
recorded in all surveyed areas. Moreover, the majority of the examined plants were liable to be infested with this snail followed by M. cartusiana and S. putris while, E. vermiculate was the lowest one in this respect. Generally, the listed hosts can be classified into three categories according to the degree of infestation. The categories were heavy, moderate and light infestation. The majority of examined crops with heavy infestation by M. cartusiana were Egyptian clover, Wheat, lettuce and Cabbage cultivated in Hehia destrict Kafer Abou-Hatab, and Hussien Timour, Abou Hammed district El-Shekh Gebil Belbies district Kafer Aioub village and Zagazig district Bani-Shebl, El-Nakkaria and Manshiet Abou Al-Akdar village, On the other hand, S. putris snail was recorded on Egyptian clover at Banadf, (Meniet El-Kaamh district), Al-Awasga, (Hehia district), Hussien timour, (Hehia district), ElShekh Gebil, (Abou Hammed district), and Kafer Aioub village (Belbies district). Regarding to E. vermiculata it was recorded on navel orange tree and ornamental plant recorded in Banadf (Meniet El-Kaamh district) and Bani- Shebl village (Zagazig district). Five species of land snails in different localities at Sharkia Governorate. There were 12 districts containing 44 localities infested with land snails, M. cartusiana, H. vestalis, C. acuta, E. vermiculata and Succinea sp. (Mahrous et al., 2002 and Shetaia 2005). Also M. cartusiana and S. putris snails were found at Sharkia Governorate. M. cartusiana snail was found with higher density than S. putris. The majority of examined crops were found with heavy infestation with M. cartusiana snail, while, S. putris was recorded with moderate or light infestation in the examined localities Shetaia et al., (2009). Four tybes of gastropods i.e. Monacha cartusiana, Monacha cantiana, Succinea putris and Deroceras laeve. 
J. Environ. Sci.

Institute of Environmental Studies and Research - Ain Shams University

Infesting several field crops i.e. wheat, Egyptian clover, broad bean, barley, maize and sugar beet as well as vegetable crops i.e. lettuce, cabbage, cucumber, kidney bean, eggplant, onion, okra, tomato, garlic, dill and parsley in 12 villages follow three districts in Sharkia Governorate Abed (2017)

Table (1): Survey of land snails and level of infestation on different Crops in certain districts at Sharkia Governorate during the Period from 2016-2017.

\begin{tabular}{|c|c|c|c|}
\hline Districts & Villages & Species & Host plant \\
\hline \multirow{4}{*}{$\begin{array}{l}\text { Meniet } \\
\text { El- } \\
\text { Kaamh }\end{array}$} & El-Karakra & M. cartusiana & $\begin{array}{c}\text { Egyptian clover }(+) \text {, Lettuce }(+), \text { Onion }(+), \text { Brood } \\
\text { bean }(+) \text {, Guava }(0) \text {, Garlic }(+) .\end{array}$ \\
\hline & \multirow{3}{*}{ Banadf } & M. cartusiana & $\begin{array}{c}\text { Egyptian clover }(++), \text { Brood bean }(+), \text { Wheat }(+), \\
\text { Cabbage }(++) .\end{array}$ \\
\hline & & S. putris & Egyptian clover $(+)$ \\
\hline & & E. vermiculata & Orange tree $(+++)$ \\
\hline \multirow{5}{*}{ Hehia } & \multirow[t]{2}{*}{ Al-Awasga } & M. cartusiana & $\begin{array}{c}\text { Egyptian clover }(+++) \text {, Onion }(+), \text { Wheat }(+), \\
\text { Brood bean }(+++) \text {, Cabbage }(++) .\end{array}$ \\
\hline & & S. putris & Egyptian clover $(+++)$ \\
\hline & $\begin{array}{l}\text { Kafr Abou } \\
\text { Hatab }\end{array}$ & M. cartusiana & $\begin{array}{c}\text { Egyptian clover }(++) \text {, Wheat }(+) \text {, Cabbage }(+++), \\
\text { Brood bean }(+) \text {, Lettuce }(+) .\end{array}$ \\
\hline & \multirow{2}{*}{$\begin{array}{l}\text { Hussien } \\
\text { Timour }\end{array}$} & M. cartusiana & $\begin{array}{l}\text { Egyptian clover }(+++) \text {, Wheat }(+), \text { Onion }(0) \text {, Brood } \\
\text { bean }(+) \text {, Cabbage }(+++) .\end{array}$ \\
\hline & & S. putris & $\begin{array}{l}\text { Egyptian clover }(+) \\
\end{array}$ \\
\hline \multirow{2}{*}{$\begin{array}{l}\text { Abou } \\
\text { Hammad }\end{array}$} & \multirow{2}{*}{$\begin{array}{l}\text { El-Sheikh } \\
\text { Gebil }\end{array}$} & M. cartusiana & $\begin{array}{l}\text { Egyptian clover }(+++) \text {, Lettuce }(+), \text { Wheat }(+), \\
\text { Onion }(+), \text { Guava }(0) \text {, Brood bean }(++) .\end{array}$ \\
\hline & & S. putris & Egyptian clover $(++)$ \\
\hline \multirow[t]{2}{*}{ Belbies } & \multirow[t]{2}{*}{ Kafr Aioub } & M. cartusiana & $\begin{array}{c}\text { Egyptian clover }(+++) \text {, Brood bean }(++), \text { Wheat }(+), \\
\text { Cabbage }(+++) \text {, Onion }(+) .\end{array}$ \\
\hline & & S. putris & Egyptian clover $(++)$ \\
\hline \multirow{4}{*}{ Zagazig } & \multirow{2}{*}{ Bani Shebl } & M. cartusiana & Egyptian clover (++), Lettuce (++), Brood bean (+). \\
\hline & & E. vermiculata & Palm tree $(++)$, Mint $(+)$, basil $(+)$ \\
\hline & $\begin{array}{c}\text { El- } \\
\text { Nakkaria } \\
\end{array}$ & M. cartusiana & $\begin{array}{c}\text { Egyptian clover }(+) \text {, Wheat }(+) \text {, Cabbage }(++), \\
\text { Brood bean }(+) .\end{array}$ \\
\hline & $\begin{array}{c}\text { Manshiet } \\
\text { Abou Al- } \\
\text { Akhdar }\end{array}$ & M. cartusiana & $\begin{array}{c}\text { Egyptian clover }(++), \text { Brood bean }(+), \text { Wheat }(+), \\
\text { Cabbage }(+) .\end{array}$ \\
\hline
\end{tabular}

$(+)=$ Low infestation (less than 15 snails $/ 0.25 \mathrm{~m} 2)$.

$(++)=$ Moderate infestation (between $15-30$ snails $/ 0.25 \mathrm{~m} 2$ ).

$(+++)=$ Heavy infestation (more than 30 snail $/ 0.25 \mathrm{~m} 2)$. 
Seasonal population dynamics of $S$. putris snail at two districts on Sharkia Governorate.: Data given in Table (2) and Fig., (2) showed that, initial infestation of S. putris appeared in the beginning at December on Egyptian clover with a relatively low population densities of $(1.6,2.8) \&(0.8$, 0.2) snails per quadrate size $50 \times 50 \mathrm{~cm}$ in the growing seasonal 2015/2016 and 2016/2017 at Hehia and Belbies districts respectively, regarding the population behavior of $\mathrm{S}$. putris after the initial infestation, it was clear that the number of snails were slightly increased to reach its peck $(27.8,35) \&$ $(37.4,42.4)$ snails per quadrate sample size $(50 \times 50 \mathrm{~cm})$ at April for growing seasonal2015/2016 and 2016/2017 at Hehia and Belbies districts respectively in Sharkia Governorate.

Generally, general mean reached $(10.07,14.4) \&(13.13,13.48)$ snails per quadrate sample size $(50 \times 50 \mathrm{~cm})$ for one seasonal2015/2016 and 2016/2017 at Hehia and Belbies districts respectively in Sharkia Governorate.

Table (2): Population dynamic of S. putris land snails during 2015/2016 And 2016/2017 on Egyptian clover at two districts in Sharkia Governorate.

\begin{tabular}{|c|c|c|c|c|c|c|c|c|}
\hline \multirow{3}{*}{$\begin{array}{c}\text { Inspection } \\
\text { date }\end{array}$} & \multicolumn{7}{|c|}{ Average number of snail's sample/ 0.25m2 } \\
\cline { 2 - 9 } & \multicolumn{2}{|c|}{ Hehia } & \multicolumn{2}{c|}{ Belbies } & \multicolumn{2}{c|}{ Temperature ${ }^{\circ}$ 岁.H. \% } \\
\cline { 2 - 9 } & $\mathbf{2 0 1 5 /}$ & $\mathbf{2 0 1 6 /}$ & $\mathbf{2 0 1 5 /}$ & $\mathbf{2 0 1 6 /}$ & $\mathbf{2 0 1 5 /}$ & $\mathbf{2 0 1 6 /}$ & $\mathbf{2 0 1 5 /}$ & $\mathbf{2 0 1 6 /}$ \\
$\mathbf{2 0 1 6}$ & $\mathbf{2 0 1 7}$ & $\mathbf{2 0 1 6}$ & $\mathbf{2 0 1 7}$ & $\mathbf{2 0 1 6}$ & $\mathbf{2 0 1 7}$ & $\mathbf{2 0 1 6}$ & $\mathbf{2 0 1 7}$ \\
\hline \hline Sep. & - & - & - & - & 29.8 & 26.95 & 54.75 & 54.5 \\
\hline Oct. & 0 & 0 & 0 & 0 & 26.47 & 26 & 53.33 & 62.2 \\
\hline Nov. & 0 & 0 & 0 & 0 & 20.97 & 21.05 & 64.7 & 55.9 \\
\hline Des. & 1.6 & 0.8 & 2.8 & 0.2 & 15.97 & 15.55 & 58.77 & 57.1 \\
\hline Jan. & 7.4 & 3.2 & 10.6 & 3 & 15.2 & 14.35 & 49.3 & 56.1 \\
\hline Feb. & 9.2 & 6.6 & 13.2 & 3.5 & 16.2 & 15.45 & 52.73 & 58.8 \\
\hline Mar. & 18 & 21.2 & 29.8 & 25.5 & 21.57 & 19.5 & 45.3 & 50.9 \\
\hline Apr. & 27.8 & 37.4 & 35 & 42.4 & 25.3 & 22.45 & 42.73 & 47 \\
\hline May & 16.6 & 36 & 24.4 & 33.6 & 27.87 & 27 & 43.1 & 41.9 \\
\hline Total & 80.6 & 105 & 115.2 & 107.9 & - & - & - & - \\
\hline Mean & 10.07 & 13.13 & 14.4 & 13.48 & - & - & - & - \\
\hline
\end{tabular}




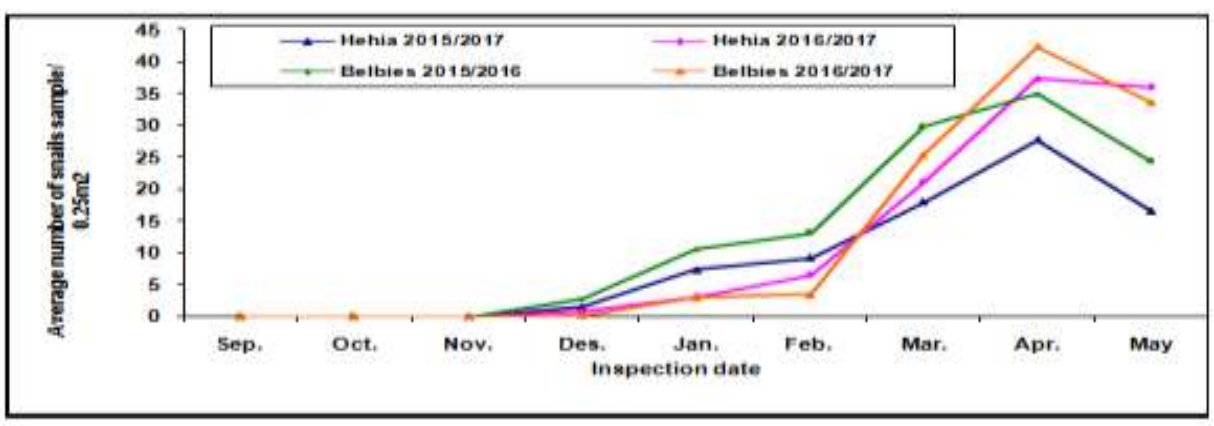

Fig. (2): Population dynamic of S. putris land snails during 2015/2016 and 2016/2017 on Egyptian clover at two districts in Sharkia Governorate.

The correlations between some climatic factors i.e. temperature and relative humidity and population density of $\mathrm{S}$. putris during the two successive growing seasons were subjected to statistical analysis. Data presented in Table (3) and Fig., (3) revealed that temperature and relative humidity showed variable effect on population density of S. putris. On Egyptian clover .Temperature showed non-significant effect on number of. S.putris during growing the two seasons also between the locations on the obesity, relative humidity showed highly significant on the population dynamic of S.putris during these growing seasons of between the locations.

Table (3): Correlation between temperatures and relative humidity on the population density of $\mathrm{S}$. putris on Egyptian clover at Hehia Belbies districts in Sharkia Governorate.

\begin{tabular}{|c|c|c|c|c|}
\hline \multirow{2}{*}{ districts } & \multicolumn{2}{|c|}{ Temperature $^{\mathbf{0}} \mathbf{C}$} & \multicolumn{2}{c|}{ Relative humidity \% } \\
\cline { 2 - 5 } & $\mathbf{2 0 1 5 / 2 0 1 6}$ & $\mathbf{2 0 1 6} / \mathbf{2 0 1 7}$ & $\mathbf{2 0 1 5 / 2 0 1 6}$ & $\mathbf{2 0 1 6 / 2 0 1 7}$ \\
\hline \hline Hehia & $0.3575 \mathrm{~ns}$ & $0.2216 \mathrm{~ns}$ & $0.0142^{*}$ & $0.0011^{* *}$ \\
\hline Belbis & $0.3841 \mathrm{~ns}$ & $0.2482 \mathrm{~ns}$ & $0.0087^{* *}$ & $0.0027^{* *}$ \\
\hline
\end{tabular}

n.s = not significant. $*=$ significant at 0.05 level. $* *=$ Highly significant at 0.05 . 


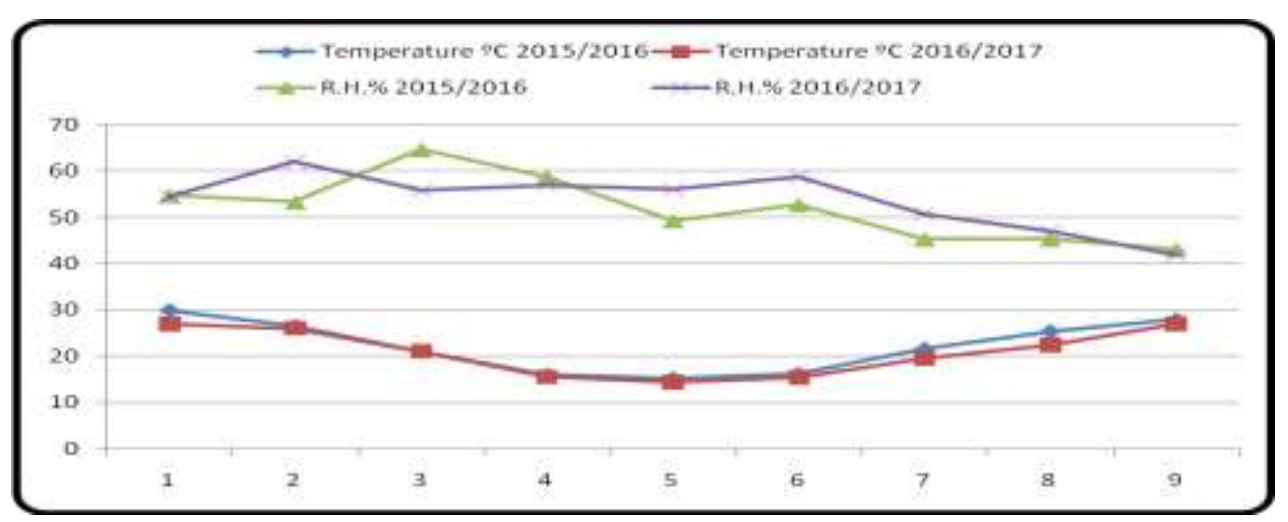

Fig. (3): Temperature and relative humidity during two successive seasons 2015/2016 and 2016/2017.

land snails of E. vermiculata were found through all over the whole year with minimum population in January and gradually increased to reach its maximum value in May Ismail, (2004). Also the land snail M. cartusiana beginning with low densities and gradually increased to reached its maximum population density in April on broad bean, pea and lettuce. Whereas Succinea putris, recorded the maximum values in April on wheat, broad bean, pea, cabbage and lettuce, while on clover and navel orange it recorded the maximum peaks in May Shetaia (2005). Investigated the population density of land snail M. cartusiana, M. cantiana, S. putris and Succinea elegans at south district of Port Saied region, Port Saied Governorate on Egyptian clover, wheat and sugar beet. Result revealed that, the maximum population density of these land snails was noticed on the soil, stems and leaves of tested crops. The maximum population density of these land snails was noticed on Egyptian clover followed by wheat and sugar beet, also the maximum population density was reports through spring season followed by autumn and winter Awad, (2013) 


\section{REFERENCES}

Abed, M. (2017): Application of some integrated control methods on some land snail's species in Sharkia governorate. Thesis for PHD. Faculty of Science, Al-Azhar University., 146pp.

Arafa, A. A. I. (1997). Studies on some land molluscs at Sharkia Governorate. M.Sc. Thesis, Fac. Agric., Al-Azhar Univ. 137 pp.

Awad, M. H. (2013): Logical control and population density studies on land snails in South district of Port Saied, Port Saied Governorate. Egypt Acad. J. Biolo. Sci., 5 (2): 47- 63.

Godan, D. (1983). Pest slugs and snails, biology and control. Springer-Verlag Berlin, Heidelberg. 445 pp.

Ismail, SH. A. (1997): Ecology, biology and control of certain terrestrial snails infesting some vegetable and field crops in Sharkia Governorate. Ph.D. Thesis, Fac. Agric. Zagazig Univ., 130pp

Ismail, SH. A. (2004): Ecobiological studies on the brown garden snail, Eobania vermiculata Muller under laboratory and field conditions in Sharkia Governorate. Zagazig J. Agric. Res., Vol. 31, No (1): $293-305$.

Lokma, M.H.E. (2007). Studies on some terrestrial gastropods injurious to field crops at Sharkia Governorate. M.Sc. Thesis, Fac. Agric., Zagazig Univ., 147pp.

Mahrous, M. E.; Ibrahim Mervat, H. and Abdel-Aal, E. M. (2002). Occurrence, population density and importance value of land snails infesting different crops in Sharkia Governorate, Egypt. Zagazig J. Agric. Res., 29(2): 613-629.

Shetaia, S. Z. S. (2005): Integrated control of land snail's pests in the fields of Sharkia Governorate. Ph.D. Thesis, Fac. Agric. Al-Azhar Univ., 150pp.

Shetaia, S. Z. S.; Ismail, Sh. A. A. and Abdel-Kader, Samah, M. (2009). Survey, population dynamics and importance value of certain land snail species infesting different crops in Sharkia Governorate. Egypt Acad. J. Biol. Sci., 1(1): 37-43. 
Staikou, A.; Lazaridou-Dimitriadou M. and Pana, E. (1990). The life cycle, population dynamics, growth and secondary production of the snail Bradybaena fruticum (Gastropoda: Pulmonata) in Northern Greece. J. Moll. Stud., 56: 137- 146.

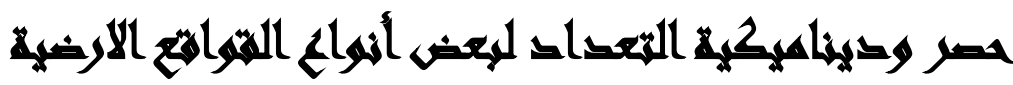

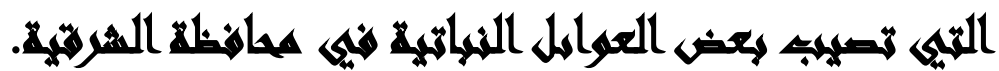

[?]

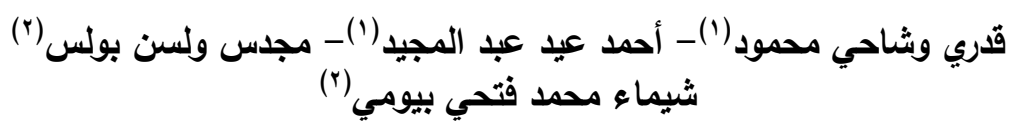

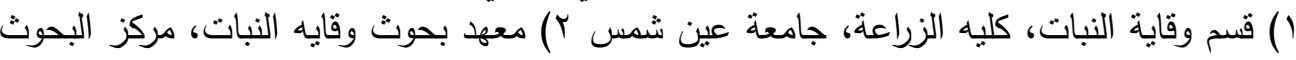

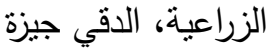

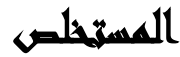

أجريت هذه الدراسه بهدف حصر بعض أنواع القواقع الارضية التي تصيب بعض النية المحاصيل

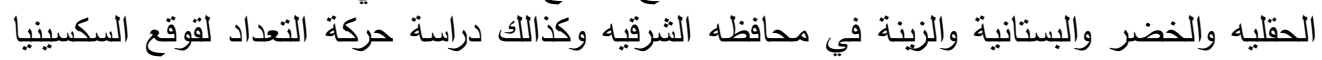

$$
\text { بوترس علي محصول البرسيم المصري. }
$$

1- دراسات حصر القواقع الأرضية في محافظة الثرقية: تمت هذه الدراسة علي عدة محاصيل

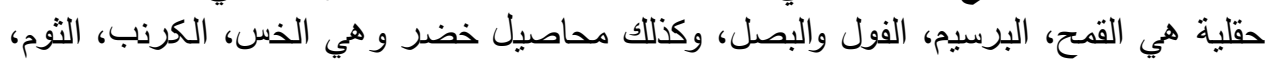

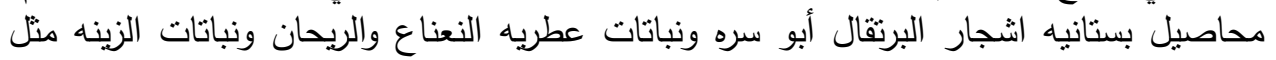

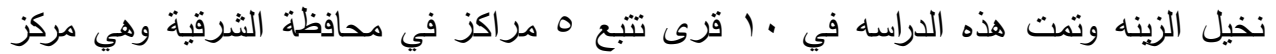

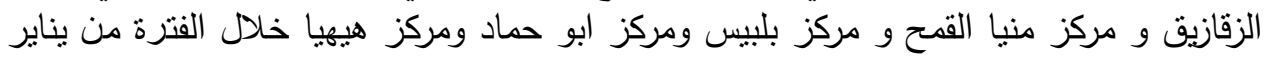

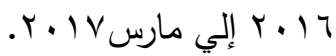

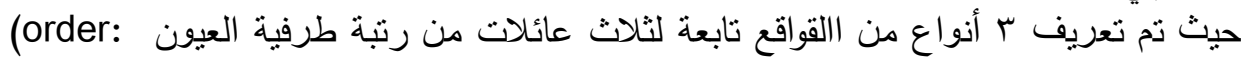

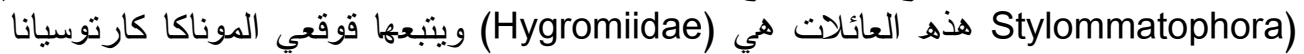

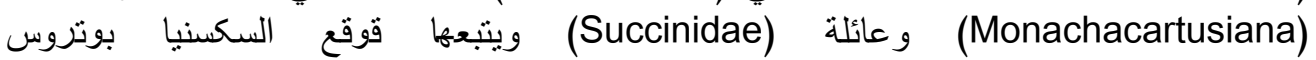
( Helicidae) (Eobania vermiculate و عائلة قوقع الاوبانيا (Succineaputris)

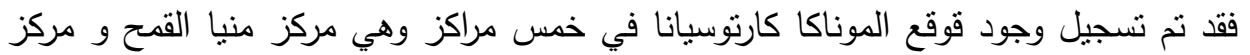

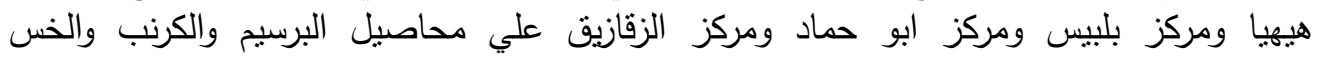

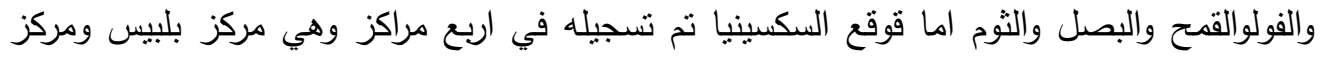
ههيا ومركز ابو حماد ومركز منيا القمح علي محصول البرسيم المصري الما بالنسبه لقوقع الاوبانيا تم 
تسجيله في مركزين فقط وهما مركز الزقازيق ومركز منيا القمح علي أشجار البرتقال أبو سره والريحان والنعناع ونخيل الزينه

r - ديناميكة التعداد لقوقع السكسينيا بوتروس علي محصول البرسيم المصري في منطقتين في

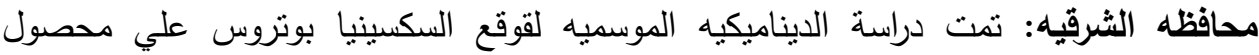

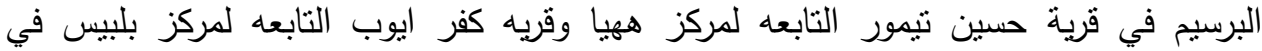

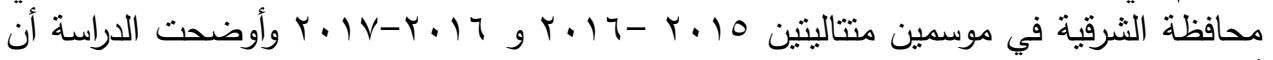

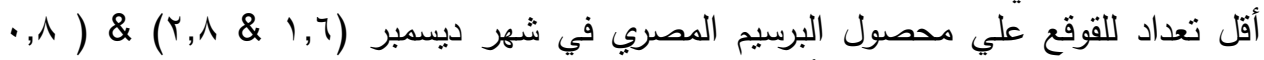

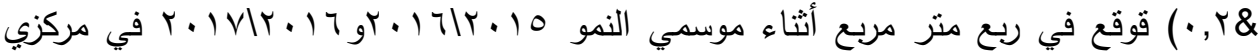

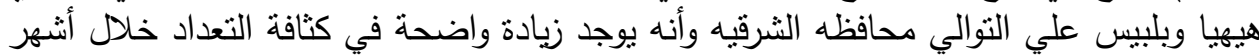

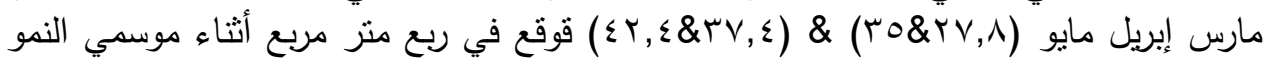

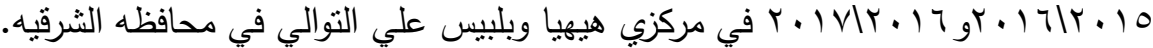

